\title{
Mir-573 regulates cell proliferation and apoptosis by targeting Bax in human degenerative disc cells following hyperbaric oxygen treatment
}

\author{
Song-Shu Lin ${ }^{1,2,3 \dagger}$, Chi-Chien Niü ${ }^{1,3,4+}$, Li-Jen Yuan ${ }^{5}$, Tsung-Ting Tsai ${ }^{1,3}$, Po-Liang Lai ${ }^{1,3}$, Kowit-Yu Chong ${ }^{3,6}$, \\ Kuo-Chen Wei ${ }^{3,7}$, Chiung-Yin Huang ${ }^{3,6}$, Meng-Ling Lu' ${ }^{8}$, Chuen-Yung Yang ${ }^{1,3}$ and Steve W. N. Ueng ${ }^{1,3,4^{*}}$
}

\begin{abstract}
Background: MicroRNA (miRNA) plays a vital role in the intervertebral disc (IVD) degeneration. The expression level of miR-573 was downregulated whereas Bax was upregulated notably in human degenerative nucleus pulposus cells. In this study, we aimed to investigate the role of miR-573 in human degenerative nucleus pulposus (NP) cells following hyperbaric oxygen $(\mathrm{HBO})$ treatment.

Methods: NP cells were separated from human degenerated IVD tissues. The control cells were maintained in 5\% $\mathrm{CO}_{2} / 95 \%$ air and the hyperoxic cells were exposed to $100 \% \mathrm{O}_{2}$ at 2.5 atmospheres absolute. MiRNA expression profiling was performed via microarray and confirmed by real-time PCR, and miRNA target genes were identified using bioinformatics and luciferase reporter assays. The mRNA and protein levels of Bax were measured. The proliferation of NPCs was detected using MTT assay. The protein expression levels of Bax, cleaved caspase 9, cleaved caspase 3, pro-caspase 9, and pro-caspase 3 were examined.

Results: Bioinformatics analysis indicated that the 3' untranslated region (UTR) of the Bax mRNA contained the "seed-matched-sequence" for hsa-miR-573, which was validated via reporter assays. MiR-573 was induced by HBO and simultaneous suppression of Bax was observed in NP cells. Knockdown of miR-573 resulted in upregulation of Bax expression in HBO-treated cells. In addition, overexpression of miR-573 by HBO increased cell proliferation and coupled with inhibition of cell apoptosis. The cleavage of pro-caspase 9 and pro-caspase 3 was suppressed while the levels of cleaved caspase 9 and caspase 3 were decreased in HBO-treated cells. Transfection with anti-miR-573 partly suppressed the effects of HBO.
\end{abstract}

Conclusion: Mir-573 regulates cell proliferation and apoptosis by targeting Bax in human degenerative NP cells following $\mathrm{HBO}$ treatment.

Keywords: MicroRNA-573, Bax, Caspase, HBO, NP

\footnotetext{
* Correspondence: wenneng@adm.cgmh.org.tw

${ }^{\dagger}$ Song-Shu Lin and Chi-Chien Niu contributed equally to this work.

'Department of Orthopaedic Surgery, Chang Gung Memorial Hospital, No 5, Fu-Hsing Street, Linkou, Taoyuan 333, Taiwan

${ }^{3}$ Hyperbaric Oxygen Medical Research Lab, Bone and Joint Research Center, Chang Gung Memorial Hospital, Taoyuan, Taiwan

Full list of author information is available at the end of the article
}

(C) The Author(s). 2021 Open Access This article is licensed under a Creative Commons Attribution 4.0 International License, which permits use, sharing, adaptation, distribution and reproduction in any medium or format, as long as you give appropriate credit to the original author(s) and the source, provide a link to the Creative Commons licence, and indicate if changes were made. The images or other third party material in this article are included in the article's Creative Commons licence, unless indicated otherwise in a credit line to the material. If material is not included in the article's Creative Commons licence and your intended use is not permitted by statutory regulation or exceeds the permitted use, you will need to obtain permission directly from the copyright holder. To view a copy of this licence, visit http://creativecommons.org/licenses/by/4.0/ The Creative Commons Public Domain Dedication waiver (http://creativecommons.org/publicdomain/zero/1.0/) applies to the data made available in this article, unless otherwise stated in a credit line to the data. 


\section{Background}

Intervertebral disc degeneration (IDD) is considered to be the pathological basis of degenerative spinal diseases, leading to intervertebral disc herniation, spinal canal stenosis, and lower back pain [1]. Apoptosis is a key component responsible for the decrease in the cell number of nucleus pulposus cells during degeneration [2, 3]. There were two apoptotic factors Bax (pro-apoptotic protein) and Bcl-2 (anti-apoptotic protein); the former binds to the mitochondrial membrane and induces the release of cytochrome $c$ [4] and the latter prevents the formation of Bax homodimers [5], which inhibits the cytosolic accumulation of cytochrome $\mathrm{c}$ and activation of caspase 3 [6]. Bcl-2 prevents or delays apoptotic induction by a large variety of stimuli in many cell types [7]. Overexpression of bcl-2 in intervertebral disc (IVD) cells reduced the mRNA expression level of caspase 3 and prevented in vitro apoptotic cell death [8].

MicroRNAs (miRNAs) are endogenous non-coding small RNAs consisting of 20-25 nucleotides that serve to mediate gene regulatory events by pairing with the $3^{\prime}$ untranslated region ( $3^{\prime}$ UTR) of their target messenger RNAs (mRNAs) and, thus, modulating their expression [9]. Various miRNAs are dysregulated in IDD and functionally implicated in its pathogenesis. MiR-21 promotes human NP cells proliferation by affecting PTEN/AKT signaling [10]. MiR-494 induced cell apoptosis via directly combining with SOX9 in human degenerative NP cells [11]. Therefore, miRNAs might play an important role in the development and progression of IDD through regulating NP cells proliferation and apoptosis.

Human IVD is the largest avascular tissue in the body [12]. During degeneration, structural changes with vascular depletion, endplate calcification, and disc size increase make oxygen diffusion harder and the oxygen concentration in the IVD becomes even lower [13]. Hyperbaric oxygen ( $\mathrm{HBO}$ ) treatment can serve to improve hypoxic conditions by increasing tissue and/or microvascular $\mathrm{O}_{2}$ levels [14]. The expression level of miR-573 was downregulated whereas Bax was upregulated notably in degenerative NP cells [15]. However, the role of miR-573 in degenerative NP cells following HBO treatment has not been fully elucidated.

In this study, we demonstrated that $\mathrm{HBO}$ treatment increased miR-573 expression in degenerated NP cells, as assessed via microarray analysis and confirmed by real-time PCR. We used bioinformatics to identify putative target sequences for miR-573 in the human Bax mRNA and confirmed these by way of luciferase reporter assays. Subsequently, we examined the cell proliferation, Bax protein, cleaved-caspase 9 protein, procaspase 9 protein, cleaved-caspase 3 protein, and procaspase 3 protein expression after $\mathrm{HBO}$ treatment. Our findings provide a new therapeutic target for the $\mathrm{HBO}$ treatment of IDD.

\section{Materials and methods}

The experimental protocol was approved by the Human Subjects Institutional Review Board at Chang Gung Memorial Hospital, Taiwan.

Preparation of human primary intervertebral disc tissue cell cultures. Fresh abnormal disk tissue was harvested from the degenerated lumbar IVD of 28 patients $($ male $=10$, female $=18$, age $=63.1 \pm 12.7)$ who receive total discectomy and posterior lumbar interbody fusion (PLIF). During the operation, the abnormal disc was explored by partial laminotomy and total facetectomy at each side. After proper protection of the existing and traversing nerve roots, the disc tissue, both annulus and nucleus, was removed massively by disc rongeur through a discotomy hole and along the path of the cage in each side until the endplates were well exposed. NP cells were separated from the nucleus tissues by performing sequential enzymatic digestion, first with $0.4 \%$ pronase (Sigma) for $1 \mathrm{~h}$ and subsequently with $0.025 \%$ collagenase P (Boehringe) and 0.004\% DNase II (Sigma) at 37 ${ }^{\circ} \mathrm{C}$ overnight. After digestion, the cells were washed with DMEM/F-12 and seeded in three fresh flasks at a density of 5000 cells $/ \mathrm{cm}^{2}$ and incubated in a humidified atmosphere of $5 \% \mathrm{CO}_{2}$ and $95 \%$ air until the cells attained confluence. Cells were used at passage 2 for each experiment.

\section{Cells exposure to intermittent $\mathrm{HBO}$}

Approximately $2 \times 10^{5}$ cells were plated on a $100-\mathrm{mm}$ cell culture dish containing $10 \mathrm{~mL}$ DMEM/F-12 supplemented with $10 \%$ FBS. The cultures were maintained at $37{ }^{\circ} \mathrm{C}$ in a humidified atmosphere of $5 \% \mathrm{CO} 2$ and $95 \%$ air. The cells were either maintained in $5 \% \mathrm{CO}_{2} / 95 \%$ air throughout the experiment as a control or in $\mathrm{HBO}$ treated protocol containing three times of $100 \%$ O2 at $1.5 \mathrm{~atm}$ (atmosphere) for $25 \mathrm{~min}$ each, two times of air break (5\% CO2/95\% air) at $1.5 \mathrm{~atm}$ for $5 \mathrm{~min}$ each in a hyperbaric chamber (Sigma II; Perry Baromedical, USA). The total duration for $\mathrm{HBO}$-treated protocol is about $120 \mathrm{~min}$. HBO treatment administered a total of $120 \mathrm{~min}$ every $48 \mathrm{~h}$.

\section{MicroRNA profiling}

Total RNA was extracted from cells using mirVana miRNA isolation kit (Ambion, Austin). MiRNA expression profiling was accomplished using TaqMan Human MicroRNA Array B Cards containing 384 mature human microRNAs (Applied Biosystems, USA) and an ABI 7900 real-time PCR System according to the manufacturer's protocol. MiRNA expression profiling was performed on eight samples from four patients (with or 
without $\mathrm{HBO}$ treatment). Briefly, $3 \mu \mathrm{L}$ of total RNA from each sample was reverse-transcribed using the Taq-Man miRNA Reverse Transcription Kit (Applied Biosystems, USA) and the stem-loop Megaplex Primer Pool Sets. A total of $7.5 \mu \mathrm{L}$ of reaction mixture was immediately incubated under the following conditions: 40 cycles at $16{ }^{\circ} \mathrm{C}$ for $2 \mathrm{~min}, 42^{\circ} \mathrm{C}$ for $1 \mathrm{~min}, 50^{\circ} \mathrm{C}$ for $1 \mathrm{~s}$, and $85^{\circ} \mathrm{C}$ for 5 min. Then, $2.5 \mu \mathrm{L}$ of the resultant Megaplex RT products were mixed with $2.5 \mu \mathrm{L}$ of Megaplex PreAmp Primers and $12.5 \mu \mathrm{L}$ of TaqMan PreAmp Master Mix. A total of $25 \mu \mathrm{L}$ of the reaction mixture was incubated using the following program: $95^{\circ} \mathrm{C}$ for $10 \mathrm{~min}, 55^{\circ} \mathrm{C}$ for $2 \mathrm{~min}$, and $72^{\circ} \mathrm{C}$ for $2 \mathrm{~min}$ followed by 12 cycles at $95^{\circ} \mathrm{C}$ for $15 \mathrm{~s}, 60^{\circ} \mathrm{C}$ for $4 \mathrm{~min}$, and $99.9^{\circ} \mathrm{C}$ for $10 \mathrm{~min}$. The pre-amplified cDNA was diluted with $0.1 \times$ TE $(10 \mathrm{mM}$ Tris, $\mathrm{pH}$ 8.0, $1 \mathrm{mM}$ EDTA) to $100 \mu \mathrm{L}$ and used for PCR. The relative miRNA expression levels were calculated by the $2^{-\Delta \Delta \mathrm{Ct}}$ method as follows: $\Delta \mathrm{Ct}$ (test) $=\mathrm{Ct}$ (miRNA of interest, test) - Ct (internal reference, test), $\Delta \mathrm{Ct}$ (calibrator) $=\mathrm{Ct}$ (miRNA of interest, calibrator) $-\mathrm{Ct}$ (internal reference, calibrator), $\Delta \Delta \mathrm{Ct}=\Delta \mathrm{Ct}$ (test) $-\Delta \mathrm{Ct}$ (calibrator). The inter-individual variability of the efficiency of our procedures was controlled by spiking of U6 snRNA. The hierarchical cluster analysis of differentially expressed miRNAs was performed using CLUSTER 3.0 [16], and the hierarchical clustering heat map was visualized by Tree View [17].

\section{Real-time PCR}

TaqMan miRNA assays (ABI PRISM; Applied Biosystems, USA) were used to detect the expression levels of the mature miR-573. For the reverse transcription (RT) reactions, $10 \mathrm{ng}$ of total RNA was mixed with the RT primer. RT reactions were performed at $16^{\circ} \mathrm{C}$ for 30 min, $42^{\circ} \mathrm{C}$ for $30 \mathrm{~min}, 85^{\circ} \mathrm{C}$ for $5 \mathrm{~min}$, and then maintained at $4{ }^{\circ} \mathrm{C}$. Following the RT reactions, $1.5 \mu \mathrm{L}$ of cDNA was used for a polymerase chain reaction (PCR) using $2 \mu \mathrm{l}$ of TaqMan primers. The PCR was conducted at $95^{\circ} \mathrm{C}$ for $10 \mathrm{~min}$ followed by 40 cycles of $95^{\circ} \mathrm{C}$ for 15 $\mathrm{s}$ and $60^{\circ} \mathrm{C}$ for $60 \mathrm{~s}$ in an ABI 7900 real-time PCR system (Applied Biosystems, USA). The fold change in the miRNA expression in each sample relative to the average expression in the control was calculated based on the threshold cycle (CT) value using the $2^{-\Delta \Delta \mathrm{Ct}}$ method.

\section{MiRNA target prediction and dual-luciferase reporter assays}

Target Scan 7.2 (http://www.targetscan.org) online software was used to analyze the putative target genes of miR-573. The 3' UTR of Bax containing the miR-573 binding site was cloned into pmirGLO dual-luciferase miRNA reporter vectors (Promega, USA). A mutated 3' UTR of Bax was introduced into the potential miR-573 binding site. The reporter vectors containing the wild- type or mutant Bax 3' UTR were transfected into NP cells using Lipofectamine 3000 (Invitrogen, USA). After incubation with or without $\mathrm{HBO}$, transfected cells were lysed. Firefly and Renilla luciferase activities were detected using the dual-luciferase assay system (Promega, USA) in accordance with the manufacturer's instructions.

\section{Transfection of NP cells with anti-miRNAs and analysis after $\mathrm{HBO}$ treatment}

NP cells were seeded into 24-well plates at a density of 2 $\times 10^{4}$ cells $/ \mathrm{cm}^{2}$ in culture medium without antibiotics and divided into control, $\mathrm{HBO}$, and $\mathrm{HBO}+$ anti-miR573 groups. The next day (day 1), cells were transfected with anti-miR-573 (100 nM; Ambion, USA) using RNAiMAX (Invitrogen, USA) and cultured in an incubator at $37{ }^{\circ} \mathrm{C}$ with $5 \% \mathrm{CO}_{2}$. After $8 \mathrm{~h}$ of transfection, the culture medium was changed to DMEM/F-12 with $5 \%$ FBS, and the cells were exposed to $\mathrm{HBO}$ treatment. Cell proliferation was measured using the 3-(4,5-dimethyl-2-thiazolyl)-2,5-diphenyl-2H tetrazolium bromide (MTT) assay. Forty-eight hours after $\mathrm{HBO}$ treatments, cells were washed once in serum-free DMEM/F-12 medium, then $900 \mu \mathrm{L} /$ well medium and $100 \mu \mathrm{L} /$ well $\mathrm{MTT}(5 \mathrm{mg} / \mathrm{mL}$ in PBS; Sigma) were added for $4 \mathrm{~h}$ at $37^{\circ} \mathrm{C}$. The dye solution was removed and cells washed once with PBS before adding $1000 \mu \mathrm{L} /$ well dimethyl sulfoxide (DMSO) and mixing in an orbital shaker for 30 to $60 \mathrm{~min}$ at room temperature in the dark. Finally, $150 \mu \mathrm{L}$ samples were removed from each well and put into 96-well plates, and absorbance was read at $570 \mathrm{~nm}$ against a blank of DMSO using a microplate reader (Dynex MRX; Dynex Technologies Ltd., UK). Data expressed the (absorbance value) ratio of $\mathrm{HBO}$ and $\mathrm{HBO}+$ anti-miR-573 to the control group.

NP cells were seeded into six-well plates at a density of $2 \times 10^{5}$ cells/well in culture medium without antibiotics. The next day (day 1), cells were transfected with antimiR-573 (100 nM) using RNAiMAX (Invitrogen) and cultured in an incubator at $37^{\circ} \mathrm{C}$ with $5 \% \mathrm{CO}_{2}$. After $8 \mathrm{~h}$ of transfection, the culture medium was changed to DMEM/ F-12 with 5\% FBS, and the cells were exposed to $\mathrm{HBO}$ treatment. On days 3 and 5, the cells were re-transfected once and exposed to $\mathrm{HBO}$. At $12 \mathrm{~h}$ after the third $\mathrm{HBO}$ treatment, cellular RNA was isolated using an RNeasy mini kit (Qiagen, USA) and reverse-transcribed into cDNA with the ImProm-II reverse transcription system (Promega, USA) for real-time PCR detection of Bax transcripts. At $24 \mathrm{~h}$ after the third HBO treatment, cells were washed with PBS and extracted using M-PER mammalian protein extraction reagent (Thermo Fisher Scientific, USA) for immunoblotting experiments. The proteins were separated via SDS-PAGE and transferred onto nitrocellulose membranes using a protein transfer unit (Bio-Rad, 
USA). After blocking with $10 \%$ nonfat milk, the membranes were incubated overnight at $4{ }^{\circ} \mathrm{C}$ with a 1000 -fold dilution of mouse antibodies against Bax (Abcam, UK) or $\beta$-actin (Abcam, UK) or a 1000-fold dilution of rabbit antibodies against procaspase-9, cleaved-caspase-9, procaspase-3, or cleaved-caspase-3 (Cell Signaling Technology, MA). After washing, the membranes were further incubated for $2 \mathrm{~h}$ with a 10,000-fold dilution of goat antimouse IgG conjugated to horseradish peroxidase (CalBiochem, USA) or goat anti-rabbit IgG conjugated to horseradish peroxidase (CalBiochem, USA). The membranes were then washed and rinsed with ECL detection reagents (Amersham Pharmacia Biotech, UK). The band images were photographed using Hyperfilm (Amersham Pharmacia Biotech, UK). The intensity of the staining for Bax, procaspase-9, cleaved-caspase-9, procaspase-3, cleaved-caspase- 3 , and $\beta$-actin was quantified using an image analysis system (Image-Pro plus 5.0; Media Cybernetics, USA).

\section{Statistical analysis}

Data are expressed as mean \pm standard deviation (SD). The $p$ value for the Student's $t$ test was calculated, and a $p$ value of $<0.05$ was considered statistically significant.

\section{Results}

Heat maps of miRNA expression in degenerated NP cells after $\mathrm{HBO}$ treatment

To identify the miRNAs involved in the molecular regulation of NP cells after HBO treatment, the miRNA expression profile of NP cells was performed using a TaqMan Human MiRNA Array B Card. As shown in Fig. 1a, there were 185 miRNAs upregulated and 37 downregulated by at least 1.5 -fold following $\mathrm{HBO}$ treatment. Among these, miR-573 was chosen for further investigation (Fig. 1b, Table 1, $n=4$ ) as previous studies revealed that miR-573 expression is lower in degenerative NPCs [15].

\section{HBO treatment increased miR-573 expression in degenerated NP cells}

HBO treatment increased miR-573 expression in NPCs (4.05 \pm 1.78 -fold, ${ }^{*} p<0.05, n=4$; Fig. $\left.1 c\right)$. These results indicated that miR-573 might play an important role in inhibiting the progression of IDD in NPCs after HBO treatment.

Seed sequence of miR-573 in the 3' UTR of the Bax mRNA To investigate the potential molecular targets of miR573, we screened for putative target genes of miR-573 using Target Scan 7.2 (http://www.targetscan.org) online software. We found that Bax, an important regulator of apoptosis, was likely a direct target of miR-573, as the 3' UTR of Bax contained a potential binding element for

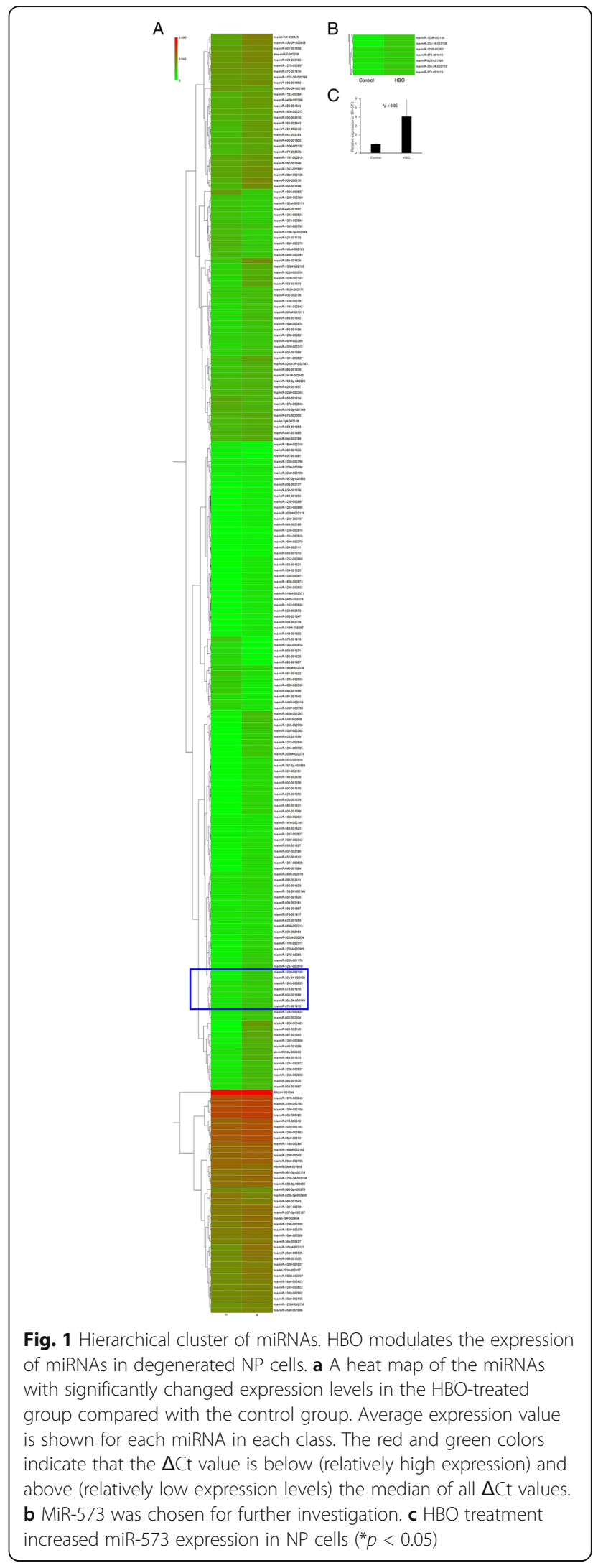


Table 1 Differentially expressed of miRNA-573 in NPCs following HBO treatment

\begin{tabular}{llllllll}
\hline Detector & Mean_DeltaCt_C & Expression_C & Mean_DeltaCt_H & Expression_H & Delta_Mean_DeltaCt & Fold_Change & Regulation \\
\hline hsa-miR-573-001615 & 23.67 & $7.48 \mathrm{E}-08$ & 22.07 & $2.28 \mathrm{E}-07$ & -1.61 & 3.04 & Up \\
\hline C & & & & &
\end{tabular}

miR-573 with a 7-nt match to the miR-573 seed region (Fig. 2a). Additionally, cross-species conservation of the miR-573 seed sequence in the 3' UTR of the Bax mRNA was confirmed by the Target Scan algorithm (Fig. 2b). These findings suggested that hsa-miR-573 might target the Bax mRNA by directly recognizing its seed-matched sequence present in the $3^{\prime}$ UTR.

\section{Bax is a direct target of miR-573}

To validate the direct targeting of Bax by miR-573, the wild type (WT) or a mutant variant (Mut) of the Bax 3' UTR containing the target sequence was cloned into a dualluciferase reporter vector (Fig. 3a). Overexpression of miR573 after HBO treatment significantly inhibited luciferase activity of the WT Bax 3' UTR (Fig. 3b, $0.53 \pm 0.06$-fold, $* * p<0.01, n=4)$, whereas mutation of the miR-573 binding sites abolished this inhibitory effect of miR-573 in the degenerated human NPCs (Fig. 3b, $1.05 \pm 0.05$-fold, $p>$ $0.05, n=4)$. These observations support the conclusion that Bax is a target gene of miR-573 following HBO treatment.

We next examined the expression of Bax in NP cells transfected with an anti-miR-573 construct. As shown in

\begin{tabular}{lrl} 
A. Targetscan & \\
\hline & $\begin{array}{c}\text { Predicted consequential pairing of target } \\
\text { region (top) and miRNA (bottom) }\end{array}$ \\
\hline Position 133-139 of BAX 3' UTR & $5^{\prime}$ & ...UGUUUUCUGACGGCAACUUCAAC... \\
Has-miR-573 & 3' & GACUAGUCAAUGUGUAGUGAAGUC
\end{tabular}

B.

\begin{tabular}{|c|c|}
\hline Human & 5'--- acggcaacuucaacu-ggggccggguug ----3' \\
\hline Mouse & 5'--- acggcaacuucaacu-ggggccgcgugg------3' \\
\hline Rat & 5'--- acggcaacuucaacu-ggggccgggugg -----3' \\
\hline Rabbit & 5'--- acggcaacuucaacu-ggggccgcguug -----3' \\
\hline Pig & 5'--- acggcaacuucaacu-ggggccgggugg ------3' \\
\hline Cow & 5'--- acggcaacuucaacu-ggggccggguug ------3' \\
\hline Cat & 5'--- acggcaacuucaacu-ggggccgggucg -----3' \\
\hline Dog & 5'--- acggcaacuucaacu-ggggccgggucg -----3' \\
\hline
\end{tabular}

Fig. 2 Seed sequence of miR-573 in the 3' UTR of the Bax mRNA. Target Scan predicted the duplex of miR-573 with the seed sequence in the 3' UTR of the human Bax mRNA. The sequences in white are the locations of the potential seed-matched sequences for the miRNAs assessed. Cross-species conservation of the miR-573 seed sequence in the 3' UTR of the human Bax mRNA as identified via the Target Scan algorithm (sequences in red) 


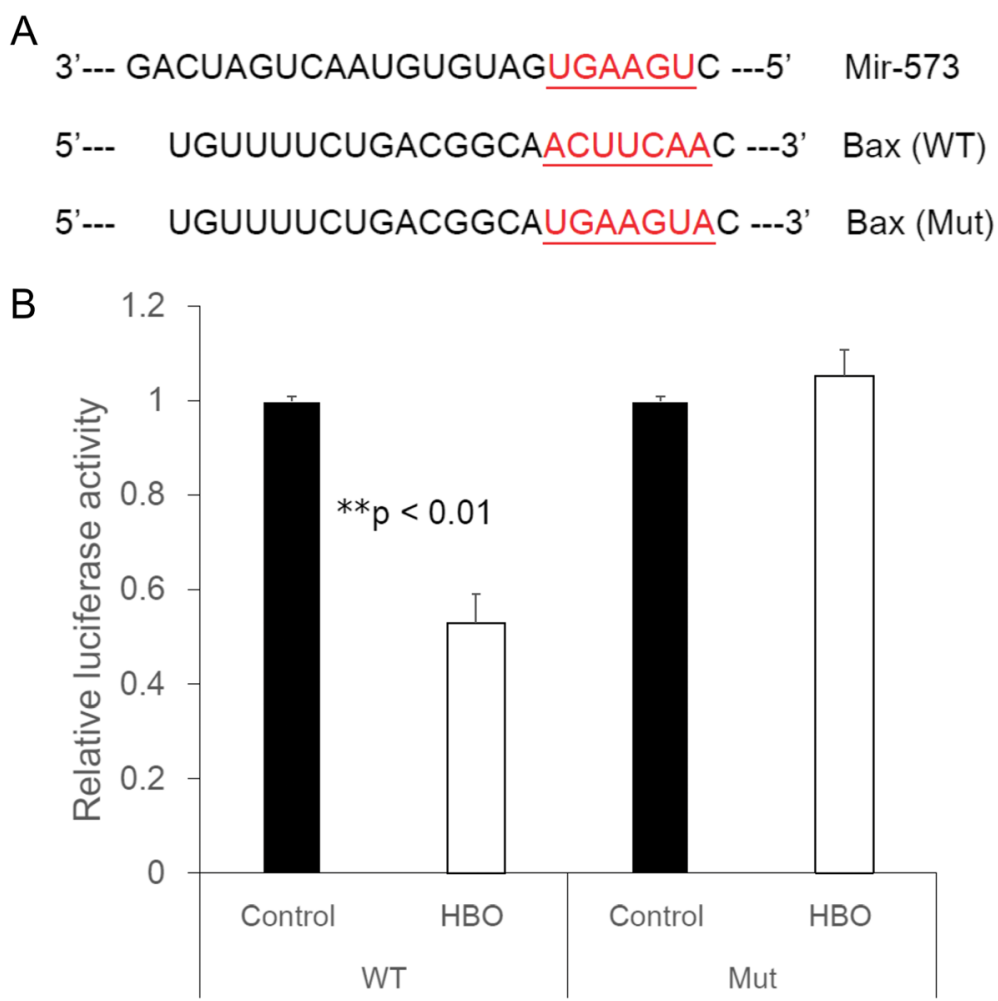

Fig. 3 Bax is a direct target of miR-573. Diagram of the binding site between miR-573 and the Bax $3^{\prime}$ UTR. The reporter vectors contain the wildtype (WT) or mutant (Mut) Bax 3' UTR. Dual-luciferase reporter assay of the Bax 3' UTR. The reporter vectors containing the WT or Mut Bax 3' UTR were transfected into NP cells. Luciferase activity was shown to be significantly downregulated after HBO treatment $\left(*^{*} p<0.01 ; n=4\right)$ in the constructs harboring the WT but not in the Mut 3' UTR $(p>0.05, n=4)$

Fig. 4a, HBO treatment decreased the mRNA expression of Bax (HBO/control: $0.56 \pm 0.09$-fold, $* * 0<0.01, n=4)$, whereas transfection with anti-miR-573 partly suppressed the effects of $\mathrm{HBO}$ treatment $(\mathrm{HBO}+$ antimiR573/control: $0.80 \pm 0.08$-fold, ${ }^{*} p<0.05, n=4$ ). Western blot analysis was performed to examine the protein level of Bax (Fig. 4b), and the results indicated that $\mathrm{HBO}$ treatment led to a significant decrease in the protein level of Bax (HBO/control: $0.55 \pm 0.08$-fold, ** $p$ $<0.01, n=4)$, whereas knockdown of miR-573 partly suppressed the effects of $\mathrm{HBO}$ treatment $(\mathrm{HBO}+$ antimiR573/Control: $0.84 \pm 0.06$-fold, $\left.{ }^{*} p<0.05, n=4\right)$. These data indicated that Bax was negatively mediated by miR-573 at the post-transcriptional level in NPCs after HBO treatment, as overexpression of miR-573 after HBO treatment significantly inhibited the mRNA (Fig. 4a) and protein (Fig. 4b) expression of Bax in these cells.

\section{Overexpression of miR-573 by HBO treatment increases cell proliferation in degenerative NP cells}

To investigate the roles of miR-573 in cell proliferation of degenerative NP cells after HBO treatment, the MTT assay was employed. As shown in Fig. 5, overexpression of miR-573 by $\mathrm{HBO}$ treatment markedly increased NP cells proliferation (HBO/control: $1.63 \pm 0.18$-fold, ${ }^{* *} p<$ $0.01, n=4)$, whereas transfection with anti-miR-573 partly suppressed the effects of HBO treatment $(\mathrm{HBO}+$ anti-miR573/control: $1.33 \pm 0.12$-fold, ${ }^{*} p<0.05, n=4$ ).

Overexpression of miR-573 by $\mathrm{HBO}$ treatment blocks the mitochondrial apoptotic pathway

To investigate whether miR-573 may regulate the mitochondrial apoptotic pathway by suppressing apoptoticassociated protein expression in NP cells following $\mathrm{HBO}$ treatment, western blotting was used to detect the cleaved-caspase 9, pro-caspase 9, cleaved-caspase 3 , and pro-caspase 3 expression levels in NPCs. It was observed that HBO treatment significantly downregulated the cleaved-caspase 9 and cleaved-caspase-3 expression, whereas transfection with anti-miR-573 partly suppressed the effects of $\mathrm{HBO}$ treatment (Fig. 6a, b for cleaved-caspase 9: $\mathrm{HBO} /$ control: $0.32 \pm 0.04$-fold, $* p<$ $0.01, n=4 ; \mathrm{HBO}+$ anti-miR-573/control: $0.59 \pm 0.10$ fold, ${ }^{*} p<0.01, n=4$; Fig. 6a, c for cleaved-caspase 3: HBO/control: $0.37 \pm 0.06$-fold, $* p<0.01, n=4 ; \mathrm{HBO}+$ anti-miR-573/control: $0.68 \pm 0.02$-fold, ${ }^{* *} p<0.01, n=$ 4). At the same time, $\mathrm{HBO}$ treatment significantly reduced the activation (cleavage) of pro-caspase 9, whereas 

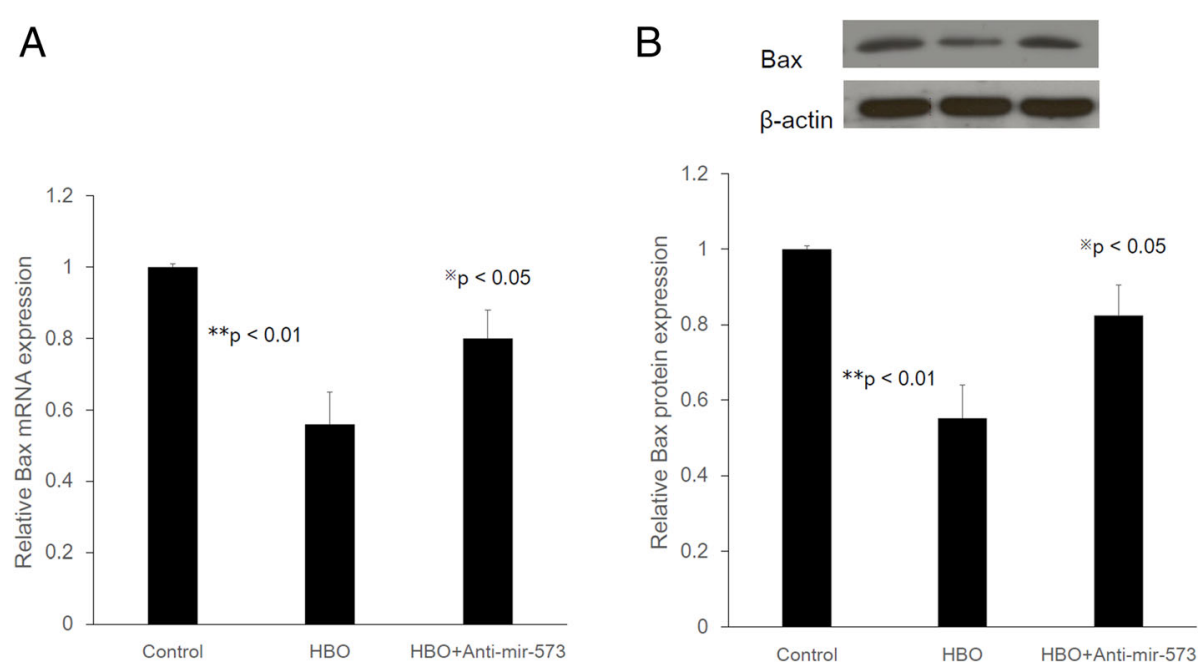

Fig. 4 Real-time PCR and Western blot analysis of Bax expression in degenerated NP cells transfected with miR-573 inhibitors following HBO treatment. a Bax mRNA expression was down-regulated after HBO treatment $\left({ }^{* *} p<0.01 ; n=4\right)$. Anti-miR-573 partly reversed the suppressive effects of $\mathrm{HBO}(* p<0.05 ; n=4)$. b Bax protein expression was significantly down-regulated after HBO treatment $(* * p<0.01 ; n=4)$. MiR-573 inhibitors partly reversed the suppressive effects of $\mathrm{HBO}\left({ }^{*}{ }_{p}<0.05 ; n=4\right)$. Values were normalized against $\beta$-actin. WT, wild type; Mut, mutant

transfection with anti-miR-573 partly suppressed the effects of $\mathrm{HBO}$ treatment (Fig. 6a, b for pro-caspase 9: $\mathrm{HBO} /$ control: $1.78 \pm 0.12$-fold, ${ }^{* *} p<0.01, n=4 ; \mathrm{HBO}+$ anti-miR-573/control: $1.43 \pm 0.11$-fold, ${ }^{*} * 0<0.01, n=$ 4 ) and pro-caspase 3 proteins (Fig. 6a, c for pro-caspase 3: $\mathrm{HBO} /$ control: $1.84 \pm 0.15$-fold, ${ }^{* * *} p<0.01, n=4 ; \mathrm{HBO}$ + anti-miR-573/control: $1.47 \pm 0.18$-fold, ${ }^{*} p<0.05, n=$ 4) in NP cells.

\section{Discussion}

Discectomy describes a class of operations used to remove part of an IVD or the entire IVD. Lumbar disc herniation (LDH) causes symptoms such as intermittent

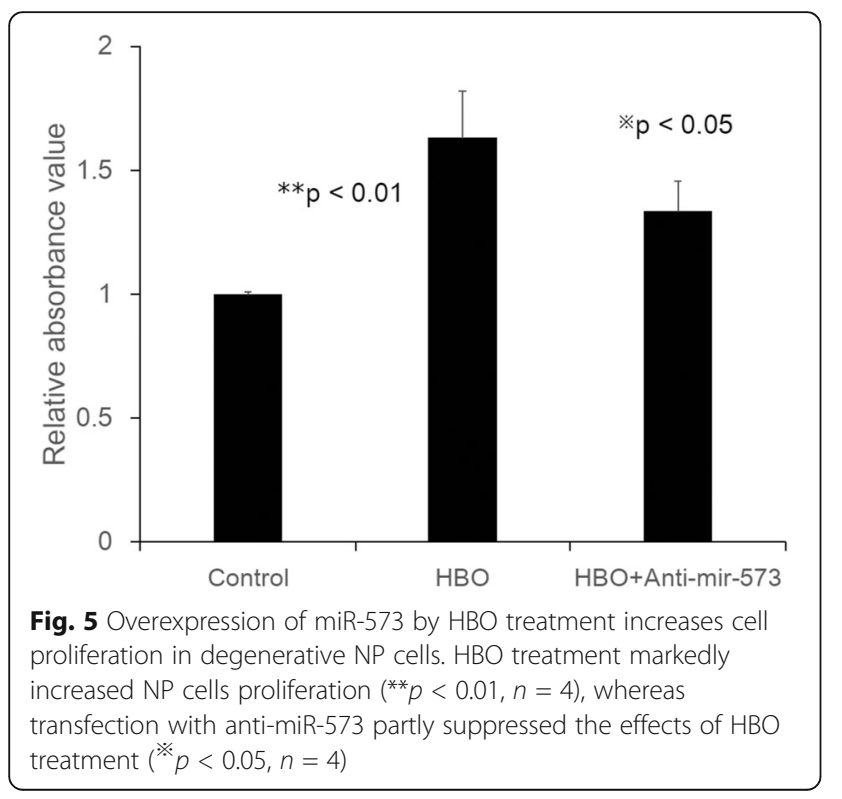

low back pain, sciatica, or patients may have more serious neurological symptoms. Lumbar microdiscectomies are always performed posteriorly (from the back) in LDH treatment, and often flavectomy and laminotomy are performed during this procedure $[18,19]$. Degenerated disc hernia (extruded or migrated disc fragments) compressing the nerve roots and/or the spinal cord were harvested, and the amount of disc degeneration was graded according to Pfirrmann classification using T2weighted MRI [20, 21].

Total discectomies, which remove the entire intervertebral disc, are usually done in concert with another procedure, such as artificial disc replacement or fusion. Total discectomies are done anteriorly (from the front). Recently, long-term data regarding total disc replacement (TDR) surgery has become available, with some studies showing superior outcomes to fusion surgery [22]. In the present study, abnormal disk tissue was harvested from the degenerated lumbar IVD of 28 patients who receive total discectomy and posterior lumbar interbody fusion and the amount of disc degeneration was also graded according to Pfirrmann classification using T2 weighted MRI $[20,21]$. Because cultures were prepared from tissues belonging to different patients in different age groups, the accuracy of the data may not be in doubt.

During degeneration, the oxygen concentration in the IVD becomes even lower than healthy IVD [13] and the expression level of miR-573 was downregulated notably in IDD tissues [15]. In addition, it has also been reported that miR-573 expression by breast cancer cells is downregulated in the presence of hypoxia [23]. MicroRNA 


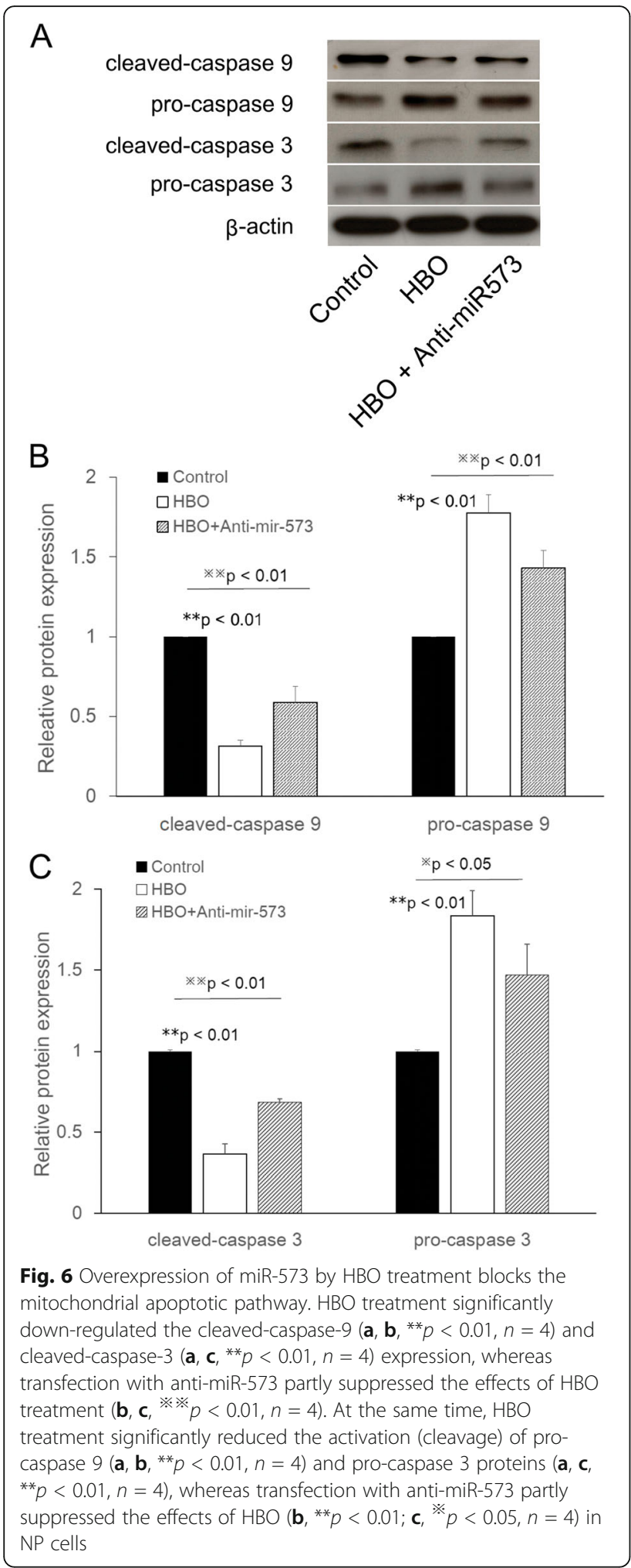

microarray analysis showed a global regulation in mature miRNA levels in cells exposed to hypoxia [24] or hyperoxia [25]. There is some evidence that hypoxic disruption of miRNA biogenesis results in a global downregulation of miRNAs in hypoxia [24]. Our data indicated that miR-573 is one of the identified miRNAs upregulated in human degenerated NPCs following HBO treatment by microarray (Fig. 1a, b) and confirmed this expression via real-time PCR (Fig. 1c). HBO treatment increases the $\mathrm{O}_{2}$ levels to improve hypoxia conditions thus may regulate the expression of miRNAs.

Bioinformatics analysis showed that Bax [15], apolipoprotein $M$ (apoM) [26], and E2F transcription factor 3 (E2F3) [27] was a potential target of hsa-miR-573 in diverse cells. Bax was the first identified pro-apoptotic member in the protein family of the B cell lymphoma-2 (Bcl-2) [28], and Bcl-2 is also a key anti-apoptotic protein [29]. Epigenetic knockdown of miR-143 regulated cell apoptosis in IDD by targeting $\mathrm{Bcl}-2$ [30]. Low expression of miR-125a was found in IDD by targeting pro-apoptotic Bcl-2 antagonist killer 1 [31]. Furthermore, the expression of miR-573 was decreased whereas that of Bax was increased oppositely in human IDD tissues [15]. HBO treatment upregulates the ratio of $\mathrm{Bcl}-2$ to Bax expression and reduced the apoptosis of ischemic tissue [32, 33] or degenerated NP cells [34]. In this study, we further found the epigenetic regulations of Bax mRNA expression. The 3' UTR of Bax containing the miR-573 binding site (Fig. 2). HBO treatment decreased luciferase activity in the WT 3' UTR of Bax compared with that of mutant forms (Fig. 3). Taken together, our present study suggested that Bax was a direct target of miR-573. Moreover, overexpression of miR-573 decreased the mRNA and protein levels of Bax (Fig. 4), which indicated a potential regulatory relationship between miR-573 and Bax following HBO treatment. HBO exerted its biological functions on NP cells via modulation of miR-573/Bax axis.

Increasing numbers of studies have demonstrated that miRNAs play vital roles in diverse pathological and biological processes by impacting on cell proliferation and apoptosis [28]. MiR-98 increased cell proliferation in NP cells [30]. Overexpression of miR-573 by mimic transfection increased cell viability in degenerated NP cells [15]. However, miR-573 upregulation inhibited melanoma cell proliferation also has been reported [35]. HBO treatment may promote [36-38] or inhibit [39] cell proliferation in diverse cell types. In consistent with previous studies, overexpression of miR- 573 by HBO treatment markedly increased NP cells proliferation, whereas transfection with anti-miR-573 partly suppressed the effects of $\mathrm{HBO}$ treatment in the present study (Fig. 5). MiR-573 overexpression increased cell proliferation and suppressed cell apoptosis in degenerative NP cells following $\mathrm{HBO}$ treatment.

Mitochondria serve an important role in the apoptotic process by releasing apoptogenic molecules, including 
cytochrome $c[40,41]$. Bax has been identified to have a pro-apoptotic effect, which may open the permeability transition pore on the mitochondrial membrane to trigger the release of cytochrome $c$ from mitochondria into the cytoplasm [42]. Cytochrome $c$ normally functions as a part of the respiratory chain, but when released into the cytosol, it becomes a critical component of the apoptosis execution machinery, where it activates caspases and causes apoptotic cell death. Cytochrome $c$ may trigger the caspase-9-molulated cascade amplification reaction in the mitochondrial apoptotic pathway, which in turn processes pro-caspase 3 to generate active caspase 3 [43]. The present results suggested that upregulation of miR-573 decreased the Bax (Fig. 4), cleaved-caspase 9, and cleaved-caspase 3 expression levels and reduced the activation (cleavage) of pro-caspase 9 and pro-caspase 3 expression levels, whereas transfection with anti-miR573 partly suppressed the effects of $\mathrm{HBO}$ treatment (Fig. 6). Collectively, these results suggested that miR-573 may exert its therapeutic effects on degenerated NP cells following $\mathrm{HBO}$ treatment by blocking the mitochondrial apoptotic pathway. However, there are some limitations in this study. Because other miRNAs may also be relevant for the regulation of apoptosis in NP cells following HBO treatment, transfection with anti-miR-573 only partly suppressed the effects of $\mathrm{HBO}$ treatment. In the future, further systematic and in-depth studies investigating the apoptosis in NP cells following HBO treatment will be conducted.

In conclusion, the results of this study indicate that HBO treatment of degenerated NP cells exerts a protective effect by mitigating apoptosis and its activation. Mir573 regulates cell proliferation and apoptosis by targeting Bax in human degenerative NP cells following HBO treatment. Recently, HBO therapy in clinical patients with full endoscopic lumbar diskectomy (FELD) has been reported [44]. The clinical applications of HBO in degenerative IVD diseases are needed to be further investigated.

\section{Abbreviations}

IDD: Intervertebral disc degeneration; NP cells: Nucleus pulposus cells; miRNAs: MicroRNAs; 3' UTR: 3' Untranslated regions; mRNAs: Messenger RNAs; HBO: Hyperbaric oxygen; MTT: 3-(4,5-dimethyl-2-thiazolyl)-2,5-diphenyl$2 \mathrm{H}$ tetrazolium bromide; WT: Wild type; Mut: Mutant variant; apoM: Apolipoprotein M; E2F3: E2F transcription factor 3

\section{Acknowledgements}

This research was supported in part by grants from the National Science Council and Chang Gung Memorial Hospital, Taiwan (CRRPG3K0061).

\section{Authors' contributions}

LSS, NCC, CKY, WKC, and USWN did the conception and design. LSS, NCC, $Y L J, Y C Y$, and LMM are responsible for the acquisition, analysis, and interpretation of the data. NCC, LSS, TTT, LPL, and HCY drafted the manuscript. All authors did the final approval of the manuscript.

\section{Funding}

Not applicable.

\section{Availability of data and materials}

We declare that the materials described in the manuscript will be freely available to all scientists for non-commercial purposes.

\section{Ethics approval and consent to participate}

The experimental protocol was reviewed and approved by the Human Subjects Institutional Review Board at Chang Gung Memorial Hospital, Taiwan.

\section{Consent for publication}

Not applicable.

\section{Competing interests}

The authors declare that they have no competing interests.

\section{Author details}

'Department of Orthopaedic Surgery, Chang Gung Memorial Hospital, No 5, Fu-Hsing Street, Linkou, Taoyuan 333, Taiwan. ${ }^{2}$ Department of Nursing, Chang Gung University of Science and Technology, Taoyuan, Taiwan. ${ }^{3}$ Hyperbaric Oxygen Medical Research Lab, Bone and Joint Research Center, Chang Gung Memorial Hospital, Taoyuan, Taiwan. ${ }^{4}$ College of Medicine, Chang Gung University, Taoyuan, Taiwan. ${ }^{5}$ Department of Orthopaedic Surgery, E-Da Hospital//-Shou University, Kaohsiung, Taiwan. ${ }^{6}$ Department of Medical Biotechnology and Laboratory Science, College of Medicine, Chang Gung University, Taoyuan 333, Taiwan. ${ }^{7}$ Department of Neurosugery, New Taipei Municipal Tu Cheng Hospital, Chang Gung Memorial Hospital and Chang Gung University, Taoyuan, Taiwan. ${ }^{8}$ Department of Orthopaedic Surgery, Chang Gung Memorial Hospital, Kaohsiung, Taiwan.

Received: 30 September 2020 Accepted: 24 November 2020

Published online: 07 January 2021

\section{References}

1. Sudo H, Yamada K, Iwasaki K, et al. Global identification of genes related to nutrient deficiency in intervertebral disc cells in an experimental nutrient deprivation model. PLoS One. 2013;8:e58806.

2. Chen B, Fellenberg J, Wang $\mathrm{H}$, et al. Occurrence and regional distribution of apoptosis in scoliotic discs. Spine. 2005;30:519-24.

3. Kim KW, Kim YS, Ha KY, et al. An autocrine or paracrine Fas-mediated counterattack: a potential mechanism for apoptosis of notochordal cells in intact rat nucleus pulposus. Spine. 2005;30:1247-51.

4. Gogvadze V, Robertson JD, Zhivotovsky B, et al. Cytochrome c release occurs via Ca2t -dependent and Ca2t - independent mechanisms that are regulated by Bax. J Biol Chem. 2001;276:19066-71.

5. Reed JC, Zha H, Aime-Sempe C, et al. Structure-function analysis of BCl-2 family proteins. Regulators of programmed cell death. Adv Exp Med Biol. 1996:406:96-112.

6. Zhao $\mathrm{H}$, Yenari MA, Cheng $\mathrm{D}$, et al. $\mathrm{BCl}-2$ overexpression protects against neuron loss within the ischemic margin following experimental stroke and inhibits cytochrome c translocation and caspase-3 activity. J Neurochem. 2003;85:1026-36.

7. Burlacu A. Regulation of apoptosis by Bcl-2 family proteins. J Cell Mol Med. 2003;7:249-57.

8. Sudo H, Minami A. Regulation of apoptosis in nucleus pulposus cells by optimized exogenous BCl-2 overexpression. J Orthop Res. 2010;28:1608-13.

9. Croce CM, Calin GA. MiRNAs, cancer, and stem cell division. Cell. 2005;122: 6-7.

10. Liu H, Huang X, Liu X, et al. miR-21 promotes human nucleus pulposus cell proliferation through PTEN/AKT signaling. Int. J Mol Sci. 2014;15:4007-18.

11. Kang L, Yang C, Song Y, et al. MicroRNA-494 promotes apoptosis and extracellular matrix degradation in degenerative human nucleus pulposus cells. Oncotarget. 2017;8:27868-81.

12. Ciapetti G, Granchi D, Devescovi V, et al. Ex vivo observation of human intervertebral disc tissue and cells isolated from degenerated intervertebral discs. Eur Spine J. 2012;21:S10-9.

13. Galbusera F, Mietsch A, Schmidt $H$, et al. Effect of intervertebral disc degeneration on disc cell viability: a numerical investigation. Comput Methods Biomech Biomed Engin. 2013;16:328-37.

14. Korhonen K, Kuttila K, Niinikoski J. Subcutaneous tissue oxygen and carbon dioxide tensions during hyperbaric oxygenation: an experimental study in rats. Eur J Surg. 1999;165:885-90. 
15. Wang R, Wen B, Sun D. MiR-573 regulates cell proliferation and apoptosis by targeting Bax in nucleus pulposus cells. Cellular \& Molecular Biology Letters. 2019;24:2.

16. Zhai Y, Li Y, Zhang J, et al. Identification of the gene cluster for bistropolone-humulene meroterpenoid biosynthesis in Phoma sp. Fungal Genet Biol. 2019;129:7-15.

17. Page RD. TreeView. Glasgow, UK: Glasgow University; 2001.

18. Somay H, Karaarslan N. Sequestrectomy or microdiscectomy in patients with lumbar disc herniation. Ann Med Res. 2019;26:753-8.

19. Lee J, Shin JS, Lee YJ, et al. Effects of Shinbaro pharmacopuncture in sciatic pain patients with lumbar disc herniation: study protocol for a randomized controlled trial. Trials. 2015;16:455.

20. Karaarslan N, Yilmaz I, Sirin DY, Ozbek H, Kaplan N, Kaya YE, et al. Pregabalin treatment for neuropathic pain may damage intervertebral disc tissue. Exp Ther Med. 2018;16:1259-65.

21. Hanley EN Jr, McCulloch JA. Surgical indication and techniques international society for the study of the lumbar spine: the lumbar spinethe lumbar spine 2nd edition. Philadelphia, PA: WB Saunders; 1996. p. pp492-524.

22. Othman YA, Verma R, Qureshi SA. Artificial disc replacement in spine surgery. Ann Transl Med. 2019;7(Suppl 5):S170.

23. Camps C, Saini HK, Mole DR, et al. Integrated analysis of microRNA and mRNA expression and association with HIF binding reveals the complexity of microRNA expression regulation under hypoxia. Mol Cancer. 2014;13:28.

24. Rupaimoole R, Wu SY, Pradeep S, et al. Hypoxia-mediated downregulation of miRNA biogenesis promotes tumour progression. Nat Commun. 2014;5: 5202.

25. Niu CC, Lin SS, Yuan L, et al. Upregulation of miR-107 expression following hyperbaric oxygen treatment suppresses HMGB1/RAGE signaling in degenerated human nucleus pulposus cells. Arthritis Research \& Therapy. 2019;21:42.

26. Hu YW, Chen ZP, Hu XM, et al. The miR-573/apoM/Bcl2A1-dependent signal transduction pathway is essential for hepatocyte apoptosis and hepatocarcinogenesis. Apoptosis. 2015;20:1321-37.

27. Chen $P$, Wang R, Yue $Q$, et al. Long non-coding RNA TTN-AS1 promotes cell growth and metastasis in cervical cancer via miR-573/E2F3. Biochem Biophys Res Commun. 2018;503:2956-62.

28. Oltvai $\mathrm{ZN}$, Milliman $\mathrm{CL}$, Korsmeyer $\mathrm{SJ}$. BCl-2 heterodimerizes in vivo with a conserved homolog, Bax, that accelerates programmed cell death. Cell. 1993;74:609-19.

29. Cleary ML, Smith SD, Sklar J. Cloning and structural analysis of CDNAs for bcl-2 and a hybrid bcl-2/immunoglobulin transcript resulting from the $t(14$; 18) translocation. Cell. 1986;47:19-28.

30. Zhao K, Zhang Y, Kang L, et al. Epigenetic silencing of miRNA-143 regulates apoptosis by targeting BCL2 in human intervertebral disc degeneration. Gene. 2017;628:259-66.

31. Liu P, Chang F, Zhang T, et al. Downregulation of microRNA-125a is involved in intervertebral disc degeneration by targeting pro-apoptotic BCl2 antagonist killer 1. Iran J Basic Med Sci. 2017;20:1260-7.

32. Godman CA, Chheda KP, Hightower LE, et al. Hyperbaric oxygen induces a cytoprotective and angiogenic response in human microvascular endothelial cells. Cell Stress Chaperones. 2010;15:431-42.

33. Qi Y, Ruan J, Wang M, et al. Effects of hyperbaric oxygen treatment on gastric cancer cell line SGC7901. Biomed Rep. 2017;6:475-9.

34. Lu XY, Cao K, Li QY, et al. The synergistic therapeutic effect of temozolomide and hyperbaric oxygen on glioma U251 cell lines is accompanied by alterations in vascular endothelial growth factor and multidrug resistance-associated protein-1 levels. J Int Med Res. 2012;40:9951004.

35. Yuan LJ, Niu CC, Lin SS, et al. Additive effects of hyperbaric oxygen and platelet-derived growth factor-BB in chondrocyte transplantation via upregulation expression of platelet-derived growth factor-beta receptor. J Orthop Res. 2009;27:1439-46.

36. Niu CC, Lin SS, Yuan L, et al. Hyperbaric oxygen treatment suppresses MAPK signaling and mitochondrial apoptotic pathway in degenerated human intervertebral disc cells. J Orthop Res. 2013;31:204-9.

37. Li Z, Yu X, Shen J, et al. MicroRNA in intervertebral disc degeneration. Cell Prolif. 2015;48:278-83.

38. Ji ML, Lu J, Shi PL, et al. Dysregulated miR-98 contributes to extracellular matrix degradation by targeting IL-6/STAT3 signaling pathway in human intervertebral disc degeneration. J Bone Miner Res. 2016;31:900-9.
39. Wang HF, Chen H, Ma MW, et al. miR-573 regulates melanoma progression by targeting the melanoma cell adhesion molecule. Oncol Rep. 2013;30: 520-6.

40. Malhotra R, Lin Z, Vincenz C, Brosius FC III. Hypoxia induces apoptosis via two independent pathways in Jurkat cells: differential regulation by glucose. Am J Physiol Cell Physiol. 2001;281:C1596-603.

41. Susin SA, Lorenzo HK, Zamzami N, et al. Molecular characterization of mitochondrial apoptosis-inducing factor. Nature. 1999;397:441-6.

42. Lu Z, Chen H, Zheng XM, Chen ML. Experimental study on the apoptosis of cervical cancer Hela cells induced by juglone through c-Jun $\mathrm{N}$-terminal kinase/c-Jun pathway. Asian Pac J Trop Med. 2017:10:572-5.

43. Zou H, Li Y, Liu X, Wang X. An APAF-1.Cytochrome $c$ multimeric complex is a functional apoptosome that activates procaspase-9. J Biol Chem. 1999;274: 11549-56.

44. Lin CH, Lin SM, Lan TY, et al. Pneumocephalus with conscious disturbance after full endoscopic lumbar Diskectomy. World Neurosurg. 2019;131:112-5.

\section{Publisher's Note}

Springer Nature remains neutral with regard to jurisdictional claims in published maps and institutional affiliations.
Ready to submit your research? Choose BMC and benefit from:

- fast, convenient online submission

- thorough peer review by experienced researchers in your field

- rapid publication on acceptance

- support for research data, including large and complex data types

- gold Open Access which fosters wider collaboration and increased citations

- maximum visibility for your research: over $100 \mathrm{M}$ website views per year

At BMC, research is always in progress.

Learn more biomedcentral.com/submissions 